\title{
Imunogenisitas dan Keamanan vaksin Tetanus Difteri [Td] pada Remaja sehagai salah satu upaya mencegah Reemerging Disease di Indonesia
}

\author{
*Eddy Fadlyana, *Kusnandi Rusmil, *Herry Garna, **Iwin Sumarman, \\ ***Soenarjati Soedigo Adi, ***Novilia Sjafri Bachtiar \\ *Departemen Ilmu Kesehatan Anak Fakultas Kedokteran, ${ }^{* *}$ Bagian Ilmu Penyakit Telinga Hidung \\ Tenggorokan, ${ }^{* * *}$ Bagian Mikrobiologi Fakultas Kedokteran Universitas Padjadjaran Rumah Sakit Dr. \\ Hasan Sadikin, Bandung, ${ }^{* * * *}$ PT Bio Farma
}

\begin{abstract}
Latar belakang. Di Indonesia berpotensi terjadi reemerging disease difteri akibat belum ada program imunisasi ulang yang berkesinambungan pada remaja.

Tujuan. Menilai imunogenisitas dan keamanan vaksin tetanus difteri (Td) yang diberikan sebagai imunisasi ulang pada remaja.

Metode. Uji klinis randomized double-blind controlled dilakukan terhadap 296 pelajar remaja sehat di kota Bandung, usia 10-18 tahun, pada September 2007-September 2008. Didapatkan 296 remaja sebagai subjek penelitian, dibagi dalam 2 kelompok secara acak sederhana. Kelompok I mendapat vaksin Td 0,5 $\mathrm{mL}$ intramuskular. Kelompok II mendapat vaksin TT sebagai kontrol. Pemeriksaan kadar antibodi anti difteri dan anti tetanus dilakukan sebelum dan 1 bulan setelah imunisasi menggunakan teknik enzymelinked immunosorbent assays (ELISAs). Data keamanan dikumpulkan sampai 1 bulan pasca imunisasi menggunakan buku harian

Hasil. Konsentrasi antibodi seroproteksi ( $\geq 0,1 \mathrm{IU} / \mathrm{mL}$ ) terhadap difteri dan tetanus mencapai $93,2 \%$ dan $100,0 \%$. The geometric mean titer (GMT) terhadap difteri meningkat dari $0,0618 \mathrm{IU} / \mathrm{mL}$ menjadi 0,7583 $\mathrm{IU} / \mathrm{mL}(\mathrm{p}<0,001)$, dan terhadap tetanus meningkat dari 0,4413 IU $/ \mathrm{mL}$ ke 14,4054 IU/mL (p<0,001). Nyeri pada tempat suntikan terjadi pada $20,3 \%$ kelompok Td dan $18,2 \%$ pada TT $(p=0,028)$. Demam $>37,5^{\circ} \mathrm{C}$ hanya terjadi pada sedikit subjek dari kedua kelompok (rentang Td: 0,7-4,7\%; rentang TT: 3,4-6,7\%). Tidak terdapat reaksi kejadian ikutan pasca imunisasi serius dan dapat ditoleransi dengan baik.

Kesimpulan. Imunisasi ulang Td meningkatkan kadar antibodi protektif terhadap difteri dan tetanus, serta aman diberikan pada remaja. Sari Pediatri 2013;15(3):141-9.
\end{abstract}

Kata kunci: imunisasi Td ulangan, antibodi, keamanan, remaja

\footnotetext{
Alamat korespondensi:

DR. Dr. Eddy Fadlyana, Sp.A(K)., M Kes.. Divisi Tumbuh Kembang Fakultas Kedokteran Universitas Padjadjaran, Rumah Sakit Dr. Hasan Sadikin, Bandung. Jl. Pasteur 38 Bandung 40161. Telp/Fax: (022) 2035957, E-mail: edfadlyana@yahoo.com
}

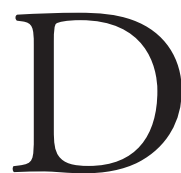

ifteri merupakan reemerging disease $e^{1,2}$ berdasarkan kejadian luar biasa (KLB) difteri di Uni Soviet pada tahun 1990an, sejak selama dua dekade sebelumnya 
difteri dapat terkendali, sejak dilakukan universal childhood immunization pada tahun 1950. Faktor yang berperan dalam terjadinya KLB adalah banyak orang dewasa yang rentan, cakupan imunisasi bayi dan ulangan (booster) yang rendah, serta kondisi sosioekonomi rendah. Walaupun demikian, sampai saat ini pengetahuan mengenai kekebalan terhadap difteri serta dampak pemberian imunisasi ulang pada remaja dan dewasa masih sangat terbatas. Pada tahun 2001 terjadi KLB difteri di kabupaten Cianjur Jawa Barat, didapatkan 112 kasus dengan angka kematian $24,1 \%$, dan paling banyak mengenai kelompok usia 5-9 tahun (51,7\%). Hasil survei tingkat kekebalan (IgG) terhadap difteri pada 698 anak di daerah KLB tersebut menunjukkan tingkat kekebalan terendah pada usia 6 tahun. ${ }^{3}$ Akhir-akhir ini kita dikejutkan dengan KLB difteri di Jawa Timur dengan 333 kasus dan 11 diantaranya meninggal, sehingga menimbulkan kepanikan akan menyebar ke berbagai daerah lainnya di Indonesia. ${ }^{4}$

Kekebalan terhadap difteri dapat diperoleh dengan cara infeksi alamiah atau pasca imunisasi. Tingkat kekebalan pasca imunisasi akan menurun seiring dengan bertambahnya usia pada saat memasuki usia remaja, sehingga kelompok remaja dan dewasa merupakan kelompok rentan mendapat difteri. Semakin lama jarak sejak mendapat imunisasi terakhir maka akan semakin rendah nilai proteksi. Volk $\mathrm{dkk}^{5}$ mendapatkan $10 \%$ anak sudah kehilangan daya proteksi terhadap difteri setelah 7-10 tahun pasca imunisasi dasar. Penelitian lain mendapatkan 10\% anak sudah tidak mempunyai proteksi setelah satu tahun pasca imunisasi dasar, 67\% setelah 3-13 tahun, dan $84 \%$ setelah $14-23$ tahun. $^{6-9}$

Dalam program imunisasi di Indonesia, imunisasi dasar pada bayi digunakan vaksin gabungan difteri, tetanus, dan pertusis (DTP), diberikan 3 kali pada usia 2, 3, dan 4 bulan. Pada kegiatan Bulan Imunisasi Anak Sekolah (BIAS), jenis imunisasi yang diberikan dapat berubah sesuai dengan kebutuhan. Misalnya untuk program tahun 2007, murid Sekolah Dasar kelas I mendapat imunisasi DT, sedangkan muridmurid kelas 2 dan 3 mendapat imunisasi tetanus toksoid (TT). ${ }^{10-11}$ Setelah kelas 3 belum diketahui apakah masih diperlukan imunisasi difteri lanjutan. Di negara maju pada kelompok remaja sampai dewasa dianjurkan menggunakan vaksin difteri yang sudah dikurangi kandungan antigen difteri (vaksin Td) untuk mengurangi efek samping. ${ }^{12-16}$ Dari data tersebut metunjukkan bahwa remaja merupakan kelompok rentan terhadap infeksi difteri sehingga harus terus terjaga status kekebalannya melalui imunisasi ulangan (booster). Vaksin difteri di pasaran tidak ada yang berisi antigen difteri saja (monovalen), tetapi merupakan vaksin kombinasi dengan tetanus. Tujuan penelitian untuk mengetahui titer antibodi spesifik ( $\mathrm{IgG}$ ) serum pada kelompok remaja terhadap difteri dan tetanus, pra dan pasca imunisasi ulang $\mathrm{Td}$.

\section{Metode}

Penelitian uji klinis, random, pra dan pasca imunisasi Td, pengamatan dilakukan secara tersamar ganda. ${ }^{17}$ Terhadap subjek yang memenuhi kriteri inklusi dilakukan pengambilan sampel darah sebelum dan 28 hari pasca imunisasi. Imunisasi menggunakan vaksin tetanus difteri $(\mathrm{Td})$, dan sebagai kontrol digunakan vaksin tetanus toksoid (TT).

Subjek penelitian adalah anak remaja sehat usia 10-18 tahun siswa sekolah SD, SMP, atau SMA di wilayah kerja Puskesmas Garuda, kota Bandung. Orangtua/wali menandatangani surat persetujuan (informed consent), setelah diberi penjelasan mengenai penelitian secara rinci. ${ }^{18,19}$

Subjek mendapatkan dosis tunggal $0,5 \mathrm{~mL}$ vaksin Td (Bio Farma) berisi 2 Lf (limit of flocculation) toksoid difteri, dan 7,5 Lf toksoid tetanus, atau mendapat vaksin TT (Bio Farma) berisi 7,5 Lf toksoid tetanus, disuntikkan intramuskular di daerah otot deltoid lengan kanan menggunakan jarum nomer. G23 dengan panjang $25 \mathrm{~mm} .{ }^{20}$ Sampel darah untuk pemeriksaan diambil sebelum dan 28 hari pasca imunisasi. Untuk menilai kadar antibodi spesifik (IgG) serum terhadap difteri dan tetanus digunakan metode enzyme-linked immunosorbent assays (ELISA), dilakukan di laboratorium Bio Farma Bandung. Titer antibodi dieukur dalam geometric mean titer (GMT). Batas protektif terhadap difteri apabila titer antibodi terhadap difteri $>0,01 \mathrm{IU} / \mathrm{mL}$ dan terhadap tetanus $>0,01 \mathrm{IU} / \mathrm{mL} \cdot .^{21,22}$

Penilaian kejadian ikutan pasca imunisasi lokal dan sistemik dilakukan dalam 24, 48, 72 jam, dan sampai 28 hari pasca imunisasi. Selama periode pemantauan setiap remaja dan orangtua mencatat kejadian, lama, serta intensitas reaksi lokal dan sistemik pada buku catatan harian. Penilaian derajat reaksi lokal menggunakan plastik yang diberi gambar lingkaran 
(derajat 1, 2, dan 3). Reaksi lokal adalah kejadian satu atau lebih reaksi pada tempat suntikan dalam 28 hari sejak imunisasi. ${ }^{13}$

Respons imun sebelum dan sesudah imunisasi dibandingkan dengan menggunakan analisis uji Wilcoxon untuk data berpasangan. Insidens kejadian lokal dan sistemik pada tiap vaksinasi diuji dengan Mc Nemar. Perbedaan antara proporsi ditentukan dengan uji chi-square atau eksak Fisher. ${ }^{23}$

\section{Hasil}

Tiga ratus subjek memenuhi kriteria inklusi pada kunjungan pertama, terdiri dari 150 subjek kelompok Td dan 150 subjek kelompok TT. Empat subjek droup out dari penilaian imunogenisitas karena tidak sesuai karena menyimpang dari prosedur protokol (protocol deviation). Subjek yang dapat dianalisis secara lengkap 296 orang remaja yang dibagi menjadi dua kelompok untuk membandingkan imunogenisitas dan keamanan antara Td dan TT. Karakteristik subjek penelitian tertera pada Tabel 1.

\section{Respons antibodi difteri dan tetanus pasca imunisasi Td}

Penilaian terhadap kekebalan yang didapat melalui imunisasi dinilai berdasarkan tolok ukur: a) peningkatan nilai GMT, b) peningkatan persentase subjek yang mempunyai kadar antibodi di atas nilai protektif, c) peningkatan persentase subjek yang memiliki titer antibodi $\geq 4$ kali, dan d) persentase subjek transisi dari seronegatif menjadi seropositif, seperti tertera pada Tabel 2.

a) Peningkatan nilai geometric mean titer (GMT) Pada kelompok Td terjadi peningkatan nilai GMT anti difteri pasca imunisasi secara bermakna $(p=0,000)$ dan terjadi peningkatan nilai GMT

Tabel 1. Karakteristik subjek penelitian

\begin{tabular}{lccc}
\hline Karakteristik & $\begin{array}{c}\text { Vaksin Td } \\
(\mathrm{n}=148)\end{array}$ & $\begin{array}{c}\text { Vaksin TT } \\
(\mathrm{n}=148)\end{array}$ & $\mathrm{p}$ \\
\hline Usia (tahun) & $43(29,0)$ & $45(30,4)$ & \\
$\quad 10-12$ & $51(34,5)$ & $60(40,5)$ & 0,364 \\
$13-15$ & $54(36,5)$ & $43(29,1)$ & \\
$16-18$ & $14,35(2,234)$ & $14,06(2,121)$ & \\
$\quad$ Rata-rata (SB) & $11 ; 18$ & $11 ; 18$ & \\
$\quad$ Min; maks & & & \\
Titer antibodi praimunisasi & $127(85,8)$ & $131(88,5)$ & 0,487 \\
- Antidifteri, IU/mL, n (\%) & $44(29,7)$ & $49(33,1)$ & 0,531 \\
$\geq 0,01$ & 0,0618 & 0,0636 & \\
$\geq 0,1$ & $(0,0504-0,0759)$ & $(0,0522-0,0777)$ & \\
GMT, IU/mL (95\% IK) & $148(100,0)$ & $148(100,0)$ & 1,0 \\
Titer antibodi tetanus, IU/mL, n (\%) & $145(97,9)$ & $146(98,6)$ & 1,1 \\
$\geq 0,01$ & 0,4413 & 0,4547 & \\
$\geq 0,1$ & $(0,3901-0,4991)$ & $(0,4062-0,5091)$ & \\
GMT, IU/mL (95\% IK GMT) & & & \\
& & & \\
Dosis vaksin mengandung DT yang per- & $5(3,4)$ & $6(4,1)$ & 0,721 \\
nah didapat, n (\%) & $3(2,0)$ & $5(3,4)$ & \\
$\quad<3$ & $124(83,8)$ & $120(81,1)$ & \\
3 & $16(10,8)$ & $17(11,5)$ & \\
4 & & & \\
Missing & & & \\
\hline
\end{tabular}

SB: standar baku 
Eddy Fadlyana dkk: Imunogenisitas dan keamanan vaksin TD pada remaja

Tabel 2. Respons antibodi terhadap difteri dan tetanus, pra dan pascai munisasi Td atau TT

\begin{tabular}{|c|c|c|c|c|}
\hline \multirow[b]{2}{*}{ Respons Antibodi } & \multicolumn{2}{|c|}{ Vaksin Td } & \multicolumn{2}{|c|}{ Vaksin TT } \\
\hline & $\begin{array}{c}\text { Pra imunisasi } \\
\mathrm{n}(\%)\end{array}$ & $\begin{array}{c}\text { Pasca imunisasi } \\
\mathrm{n}(\%)\end{array}$ & $\begin{array}{c}\text { Pra imunisasi } \\
\mathrm{n}(\%)\end{array}$ & $\begin{array}{c}\text { Pasca imunisasi } \\
\mathrm{n}(\%)\end{array}$ \\
\hline \multicolumn{5}{|l|}{ Anti difteri (IU/mL) } \\
\hline$\geq 0,01$ & $127(85,8)$ & $147(99,3)$ & $131(88,5)$ & $133(89,9)$ \\
\hline$\geq 0,1$ & $44(29,7)$ & $138(93,2)$ & $49(33,1)$ & $52(35,1)$ \\
\hline GMT & 0,0618 & 0,7583 & 0,0636 & 0,0685 \\
\hline$(95 \% \mathrm{IK})$ & $(0,0504-0,0759)$ & $(0,6133-0,9377)$ & $(0,0522-0,0777)$ & $0,0558-0,0840$ \\
\hline \multicolumn{5}{|l|}{ Anti tetanus (IU/mL) } \\
\hline$\geq 0,01$ & $148(100,0)$ & $148(100,0)$ & $148(100,0)$ & $148(100,0)$ \\
\hline$\geq 0,1$ & $145(97,9)$ & $148(100,0)$ & $146(98,6)$ & $148(100,0)$ \\
\hline GMT & 0,4413 & 14,4054 & 0,4547 & 21,2332 \\
\hline$(95 \% \mathrm{IK})$ & $(0,3901-0,4991)$ & $(12,65805-16,39396)$ & $(0,4062-0,5091)$ & $(18,3298-24,5965)$ \\
\hline \multicolumn{5}{|l|}{$\begin{array}{l}\text { Persentase subjek dengan peningkat- } \\
\text { an titer antibodi } \geq 4 \text { kali }\end{array}$} \\
\hline Anti difteri & - & $117(86,7)$ & - & $3(2,2)$ \\
\hline Anti tetanus & - & $143(96,6)$ & - & $147(98,6)$ \\
\hline \multicolumn{5}{|l|}{$\begin{array}{l}\text { Persentase subjek dg transisi dari } \\
\text { seronegatif menjadi seropositif }\end{array}$} \\
\hline Anti difteri & - & $20(95,2)$ & - & $2(11,8)$ \\
\hline Anti tetanus & - & NA & - & NA \\
\hline $\begin{array}{l}\text { Perbedaan untuk antidifteri } \\
\text { Kelompok Td: pra vs pasca imunisasi: p } 0,0000 \\
\text { Kelompok TT: pra vs pasca imunisasi: p } 0,0753 \\
\text { Pascaimunisasi: Kelompok Td vs TT: p 0,0000 }\end{array}$ & & $\begin{array}{l}\text { Perbedaan untul } \\
\text { Kelompok Td: } \mathrm{p} \\
\text { Kelompok TT: : } \\
\text { Pascaimunisasi: }\end{array}$ & $\begin{array}{l}\text { antitetanus } \\
\text { ra vs pasca imunisasi: } \mathrm{p} \\
\text { ra vs pasca imunisasi: } \mathrm{p} \\
\text { Kel Td vs TT: } \mathrm{p} 0,0001 \\
\end{array}$ & 0,0000 \\
\hline
\end{tabular}

anti tetanus pasca imunisasi secara bermakna $(\mathrm{p}=0,000)$.

b) Persentase subjek yang mempunyai kadar antibodi di atas nilai protektif

Subjek yang mempunyai kadar di atas nilai protektif terhadap difteri $(0,01 \mathrm{IU} / \mathrm{mL})$ pada kelompok Td 99,3\% dan pada kelompok TT $89,9 \%$. Apabila dilihat dari perolehan titer protektif anti difteri jangka panjang $(\geq 0,1 \mathrm{IU} /$ $\mathrm{mL}$ ), maka tampak perbedaan yang lebih besar, yaitu pada kelompok Td 93,2\%, sedangkan pada kelompok TT 35,1\%.

c) Persentase subjek dengan peningkatan titer antibodi $\geq 4$ kali

Pada kelompok Td, persentase subjek dengan peningkatan titer antibodi anti difteri $\geq 4$ kali $86,7 \%$ dan antitetanus $96,6 \%$. Sedangkan pada kelompok TT terhadap anti difteri $2,2 \%$ dan anti tetanus $98,6 \%$. d) Persentase subjek transisi dari seronegatif menjadi seropositif anti difteri

Pada kelompok Td, persentase subjek yang mengalami transisi dari seronegatif menjadi seropositif terhadap anti difteri 95,2\%. Pada kelompok TT, persentase subjek yang mengalami transisi dari seronegatif menjadi seropositif terhadap antidifteri $11,8 \%$.

\section{Keamanan vaksin}

Penilaian keamanan dilakukan pada kedua kelompok ( $\mathrm{n}=296)$, masing-masing kelompok Td dan TT 148 orang. Berdasarkan waktu kejadiannya maka reaksi keamanan dinilai 30 menit, 30-72 jam, dan 72 jam-28 hari pascaimunisasi.

\section{a. Pemantauan 30 menit pascaimunisasi}

Reaksi lokal

- Nyeri pada tempat suntikan terjadi pada 
Eddy Fadlyana dkk: Imunogenisitas dan keamanan vaksin TD pada remaja

Tabel 3. Reaksi lokal dan sistemik pada 30 menit-72 jam pasca imunisasi

\begin{tabular}{|c|c|c|c|c|c|c|c|}
\hline & \multicolumn{3}{|c|}{ Kelompok Td (N=148) } & \multicolumn{3}{|c|}{ Kelompok TT $(\mathrm{N}=148)$} & \multirow{2}{*}{$\mathrm{p}$} \\
\hline & Intensitas & $\mathrm{n}$ & $\%$ & Intensitas & $\mathrm{n}$ & $\%$ & \\
\hline \multicolumn{8}{|l|}{ Lokal } \\
\hline \multirow[t]{4}{*}{ Nyeri } & Ringan & 35 & 23,3 & Ringan & 40 & 27,0 & \multirow[t]{4}{*}{0,687} \\
\hline & Sedang & 6 & 4,1 & Sedang & 10 & 6,7 & \\
\hline & Berat & 4 & 2,7 & Berat & 7 & 4,7 & \\
\hline & Jumlah & 45 & 30,4 & Jumlah & 57 & 38,5 & \\
\hline \multirow[t]{4}{*}{ Kemerahan } & Ringan & 19 & 12,8 & Ringan & 28 & 18,9 & \multirow[t]{4}{*}{0,709} \\
\hline & Sedang & 2 & 1,3 & Sedang & 2 & 1,3 & \\
\hline & Berat & 0 & 0,0 & Berat & 0 & 0,0 & \\
\hline & Jumlah & 21 & 14,2 & Jumlah & 30 & 20,3 & \\
\hline \multirow[t]{4}{*}{ Bengkak } & Ringan & 15 & 10,0 & Ringan & 25 & 16,7 & \multirow[t]{4}{*}{0.337} \\
\hline & Sedang & 3 & 2,0 & Sedang & 1 & 0,7 & \\
\hline & Berat & 1 & 0,7 & Berat & 1 & 0,7 & \\
\hline & Jumlah & 19 & 12,7 & Jumlah & 27 & 18,0 & \\
\hline \multirow[t]{4}{*}{ Indurasi } & Ringan & 9 & 6,1 & Ringan & 13 & 8,8 & \multirow[t]{4}{*}{0,219} \\
\hline & Sedang & 8 & 5,4 & Sedang & 0 & 0,0 & \\
\hline & Berat & 1 & 0,7 & Berat & 0 & 0,0 & \\
\hline & Jumlah & 18 & 12,2 & Jumlah & 13 & 8,8 & \\
\hline \multicolumn{8}{|l|}{ Sistemik } \\
\hline \multirow[t]{4}{*}{ Demam } & Ringan & 7 & 4,7 & Ringan & 9 & 6,0 & \multirow[t]{8}{*}{0,388} \\
\hline & Sedang & 0 & 0,0 & Sedang & 1 & 0,7 & \\
\hline & Berat & 0 & 0,0 & Berat & 0 & 0,0 & \\
\hline & Jumlah & 7 & 4,7 & Jumlah & 10 & 6,7 & \\
\hline \multirow[t]{4}{*}{ Lain-lain } & Ringan & 7 & 4,7 & Ringan & 9 & 6,0 & \\
\hline & Sedang & 0 & 0,0 & Sedang & 0 & 0,0 & \\
\hline & Berat & 0 & 0,0 & Berat & 0 & 0,0 & \\
\hline & Jumlah & 7 & 4,7 & Jumlah & 9 & 6,0 & \\
\hline
\end{tabular}

20,3\% kelompok Td dan 18,2\% pada kelompok TT, tidak berbeda secara bermakna $(\mathrm{p}=0,028)$

- Kemerahan dilaporkan pada 4,1\% kelompok Td dan 3,4\% pada kelompok TT, tidak berbeda bermakna $(\mathrm{p}=0,387)$

- Pada kedua kelompok reaksi lokal yang terjadi pada umumnya ringan.

Reaksi sistemik

- Kejadian demam terjadi pada kedua kelompok sangat sedikit, yaitu satu subjek pada kelompok Td dan lima subjek pada kelompok TT.

b. Pemantauan pada 30 menit-72 jam pasca imunisasi

\section{Reaksi lokal}

- Nyeri pada tempat suntikan terdapat
$30,4 \%$ pada kelompok Td dan 38,5\% pada kelompok TT, tidak berbeda bermakna $(p=0,687)$ seperti tertera pada Tabel 3.

- Kemerahan tercatat pada 14,2\% kelompok Td dan 20,3\% pada kelompok TT, tidak berbeda bermakna $(\mathrm{p}=0,709)$. Reaksi lokal tersebut pada umumnya ringan.

- $\quad$ Bengkak terjadi pada $12,7 \%$ kelompok Td dan $18 \%$ pada kelompok TT, tidak berbeda bermakna $(\mathrm{p}=0,337)$.

- Indurasi terjadi pada 12,2\% kelompok Td dan 8,8\% pada kelompok TT, tidak berbeda bermakna $(\mathrm{p}=0,219)$.

\section{Reaksi sistemik}

- Demam terjadi pada 4,7\% kelompok Td dan 6,0\% pada kelompok TT, tidak berbeda bermakna $(p=0,388)$. 
c. Pemantauan pada 4-28 hari pasca imunisasi

Reaksi lokal dan kejadian sistemik yang terjadi 4-28 hari pasca imunisasi sudah hampir hilang seluruhnya. Dari kelompok Td sudah tidak ada reaksi lokal maupun sistemik sedangkan dari kelompok TT reaksi lokal yang masih ada berupa nyeri dan indurasi ringan masing-masing pada 1 subjek $(0,7 \%)$.

\section{Pembahasan}

Kami telah meneliti 296 remaja usia 10-18 tahun yang merupakan kelompok risiko untuk mendapat infeksi difteri karena imunisasi pada remaja saat ini belum mendapat perhatian yang memadai, baik dari masyarakat maupun dari pemerintah. Hal tersebut disebabkan anggapan imunisasi yang diberikan pada masa anak-anak dianggap sudah cukup dan akan berlangsung seumur hidup. Di samping itu, daya tahan tubuh remaja dianggap sudah baik sehingga apabila sakit, tidak berat, dan tidak sampai meninggal. ${ }^{24}$

Hasil penelitian kami menunjukkan persentase remaja yang masih mempunyai kadar anti difteri dan anti tetanus di atas nilai protektif $(\geq 0,01 \mathrm{IU} / \mathrm{mL})$ pra imunisasi berturut-turut $81,8 \%$ dan 100\%. Angka yang tinggi kemungkinan hasil dari Program BIAS ${ }^{10}$ yang secara rutin dilakukan di sekolah dasar saat kelas 1, dengan menggunakan vaksin DT. Hasil tersebut sesuai dengan penelitian yang dilakukan Isbagio $\mathrm{dkk}^{25}$ terhadap antibodi difteri dan tetanus satu tahun setelah mendapat imunisasi DT pada 58 anak usia 5-6 tahun yang mempunyai riwayat imunisasi dasar DPT 3 kali, 96,5\% masih mempunyai kadar antibodi di atas nilai proteksi terhadap difteri dan $100 \%$ terhadap tetanus.

Imunisasi sudah terbukti dapat menurunkan angka kejadian dan kematian penyakit yang dapat dicegah dengan imunisasi, akan tetapi cakupan imunisasi DPT3 secara nasional masih rendah, yaitu sekitar $60 \%$ dari sasaran, sehingga masih banyak anak balita yang belum mendapat imunisasi secara lengkap. ${ }^{26-29} \mathrm{Hal}$ tersebut berpotensi untuk timbulnya KLB di berbagai tempat di Indonesia. Pada awal Maret 2000, dilaporkan KLB difteri di Cikalong Wetan Kabupaten Cianjur Jawa Barat, terdapat 25 kasus dengan CFR 28\% (tujuh kasus). Jumlah pasien dirawat 21 orang, terdapat tujuh orang $(55 \%)$ di bawah usia 5 tahun, penyebab kematian terutama akibat miokarditis. Walaupun cakupan imunisasi DPT tinggi, hanya 11 (19,3\%) orang yang memiliki kadar antibodi di atas nilai proteksi jangka panjang (titer anti difteri $\geq 0,1 \mathrm{IU} / \mathrm{mL}$ ), titer antibodi mulai menurun pada kelompok usia 1-2 tahun, dan tidak terdapat subjek yang memiliki titer di atas nilai proteksi pada usia 5-6 tahun $(<0,01)$. Enam $(1,9 \%)$ dari 324 kultur apus tenggorok menunjukkan pertumbuhan Corynebacterium diphtheriae tipe gravis. Penelitian tersebut menyimpulkan bahwa anak-anak di daerah KLB mempunyai tingkat kekebalan terhadap difteri yang rendah, sehingga memudahkan terjadi infeksi oleh Corynebacterium diphtheriae yang toksik dan bersirkulasi di masyarakat, hal inilah yang menjadi penyebab KLB di daerah tersebut. ${ }^{8}$

Penelitian kami menunjukkan bahwa imunisasi Td meningkatkan tingkat proteksi terhadap difteri dan menjaga proteksi terhadap tetanus tetap tinggi $(100 \%)$. Peningkatan kekebalan terhadap difteri tercermin dengan peningkatan GMT dari 0,0618 $\mathrm{IU} / \mathrm{mL}$ menjadi $0,7583 \mathrm{IU} / \mathrm{mL}$; terhadap tetanus GMT meningkat dari $0,4413 \mathrm{IU} / \mathrm{mL}$ menjadi $14,4054 \mathrm{IU} / \mathrm{mL}$. Proteksi jangka panjang terhadap difteri meningkat dari 29,7\% menjadi 93,2\% dan terhadap tetanus dari $97,9 \%$ menjadi $100 \%$. Subjek pada kelompok kontrol (TT) tidak menunjukkan peningkatan kekebalan terhadap difteri. Berdasarkan hal tersebut dapat diambil kesimpulan bahwa meningkatnya daya kekebalan terhadap difteri dan tetanus adalah dampak dari pemberian imunisasi, yaitu peran sel memori yang masih aktif pada masa remaja. Sel memori yang terbentuk pada respons imun primer akan cepat mengalami transformasi blas, proliferasi, dan diferensiasi menjadi sel plasma yang menghasilkan antibodi. Demikian pula dengan imunitas selular, sel limfosit $\mathrm{T}$ akan lebih cepat mengalami transformasi blas dan berdiferensiasi menjadi sel $\mathrm{T}$ aktif, sehingga lebih banyak terbentuk sel efektor dan sel memori. ${ }^{7,9,11,22,30-31}$ Penelitan terdahulu yang dilakukan oleh Pichichero $\mathrm{dkk}^{32}$ di Amerika Serikat menggunakan vaksin $\mathrm{Td}$ terhadap 834 remaja usia 10-18 tahun, memperlihatkan peningkatan GMC antidifteri dari 0,34 menjadi $14,02 \mathrm{IU} / \mathrm{mL}$ dan GMC antitetanus dari 0,73 menjadi 20,72 IU/ $\mathrm{mL}$. Hasil tersebut menunjukkan bahwa dengan 5 kali mendapat imunisasi yang mengandung komponen difteri sejak umur 2 bulan memiliki proteksi terhadap $92,1 \%$ remaja.

Respons anti tetanus pada remaja pada kelompok Td lebih rendah dibandingkan dengan kelompok TT (GMT 14,4054 vs 21,2332 IU/mL). Hasil 
tersebut perlu mendapat perhatian untuk penelitian selanjutnya. Pada umumnya subjek yang menerima vaksin kombinasi dapat memberikan hasil yang lebih rendah dibandingkan dengan vaksin bukan kombinasi (TT), kemungkinanan disebabkan oleh kompetisi masing-masing antigen.walaupun demikian titer antibodi masih di atas nilai proteksi. ${ }^{16}$

Kedua kelompok memperlihatkan toleransi yang baik terhadap reaksi lokal, maupun kejadian sistemik. Selama 30 menit pertama pasca imunisasi reaksi lokal yang tercatat berupa nyeri, kemerahan, bengkak, indurasi dan kejadian demam tidak berbeda antara kelompok Td dan kelompok TT. Demikian pula selama pemantauan 30 menit-72 jam pasca imunisasi reaksi lokal dan kejadian demam pada kedua kelompok tidak ada perbedaan. Pada 4-28 hari pasca imunisasi kedua kelompok sudah tidak ditemukan lagi reaksi lokal maupun kejadian sistemik, kecuali indurasi terjadi pada 1 orang subjek dari kelompok TT. Reaksi lokal di tempat suntikan dan kejadian sistemik pasca imunisasi dipengaruhi oleh jumlah dosis difteri dan tetanus yang sudah diterima, cara pemberian serta tingkat anti tetanus yang dimiliki penerima vaksin. Seseorang yang sudah memiliki titer anti tetanus yang tinggi mempunyai risiko lebih tinggi terjadi reaksi lokal maupun kejadian sistemik. ${ }^{13,33,34}$ Berdasarkan laporan yang dihimpun oleh $\mathrm{WHO},{ }^{13}$ imunisasi $\mathrm{Td}$ menyebabkan reaksi lokal berupa nyeri, indurasi, dan kemerahan pada 10\%-75\% kasus. Pada beberapa kasus, terdapat indurasi yang berlangsung dalam beberapa minggu. Abses steril terjadi pada 6-10 kasus per 1 juta dosis. Demam dan kejadian sistemik lainnya (nyeri otot dan nyeri kepala) terjadi pada $10 \%$ kasus. Pada penelitian dengan menggunakan vaksin Tdap (tetanus, difteri, dan pertusis aselular) yang diberikan dosis tunggal pada remaja usia 10-18 tahun memberikan hasil yang aman dan imunogenik dibandingkan dengan yang diberikan Td. Vaksin Tdap dan vaksin Td sama amannya apabila diberikan pada remaja. ${ }^{32}$ Untuk menjaga agar seseorang mempunyai tingkat kekebalan yang selalu tinggi terhadap difteri dan tetanus diperlukan imunisasi yang berkesinambungan sejak masa bayi. Imunisasi primer terhadap tetanus neonatorum pada bayi akan memberikan kekebalan 94\%-100\% selama 1-3 tahun. ${ }^{33,34}$ Pemberian imunisasi ulang (booster)/ dosis ke-4 akan memberikan tambahan kekebalan selama 5 tahun, sampai usia 6-7 tahun. Dosis ke-5 toksoid tetanus diberikan dengan vaksin $\mathrm{Td}$ atau DT pada saat masuk sekolah akan memberikan tambahan kekebalan selama 10 tahun, yaitu sampai usia 17-18 tahun. Akhirnya pemberian dosis tambahan pada saat akan meninggalkan bangku sekolah akan memberikan cukup kekebalan sampai paling sedikit selama 20 tahun. ${ }^{10}$ Di Indonesia, masih belum tersedia data tingkat proteksi terhadap difteri dan tetanus pada usia 15-18 bulan dan pada usia dewasa serta respons imun setelah imunisasi ulang pada kedua kelompok tersebut. Dapat disimpulkan bahwa pemberian imunisasi ulang $\mathrm{Td}$ memberikan peningkatan titier antibodi protektif terhadap difteri dan tetanus, serta aman diberikan pada remaja usia 10-18 tahun. Sudah saatnya imunisasi ulang $\mathrm{Td}$ pada remaja menjadi program nasional sehingga kehawatiran terjadinya reemerging disease dapat dicegah.

Penelitian kami mempunyai keterbatasan, data riwayat imunisasi yang lalu didasarkan pada wawancara terhadap orangtua karena pada umumnya sudah tidak memiliki Kartu Menuju Sehat.

\section{Ucapan terima kasih}

Ucapan terima kasih ditujukan kepada Direktur Utama PT Bio Farma Bandung beserta jajarannya yang sudah memberikan kemudahan penggunaan fasilitas dan dukungan dana penelitian.

\section{Daftar pustaka}

1. Schwartz DA. Emerging and reemerging infectious. Progress and challenges in the subspecialty of infectious disease pathology. Arch Pathol Lab Med 1997;121:77684.

2. Vitek CR, Wharton M. Diphtheria in the Former Soviet Union: reemergence of a pandemic disease.Emerg Infect Dis. 1998;4: (diunduh 13 September 2010). Didapat dari://www.cdc.gov/ ncidod/eid/vol.4 no.4/vitek.htm

3. Rusmil K, Fadlyana E, Dhamayanti M, Chairulfatah A. Wabah difteri di kecamatan Cikalong Wetan, Kabupaten Cianjur, Jawa Barat, Indonesia. Sari Pediatri 2011;12:397-403.

4. Profil Kesehatan Provinsi JawaTimur 2010. Surabaya: Dinas Kesehatan Jatim; 2011.

5. Volk VK, Gottshall RY, Anderson HD, Top FH, Bunney WE, Serfling RE. Antigenic response to booster dose of diphtheria and tetanus toxoids seven to thirteen years after primary inoculation of non institutionalized 
Eddy Fadlyana dkk: Imunogenisitas dan keamanan vaksin TD pada remaja

children. Public Health Rep 1962;77:185-94.

6. Crossley K, Irvine P, Warren JB, Lee BK, Mead K. Tetanus and diphtheria immunity in urban Minnesota adults. JAMA 1979;242:2298-300.

7. Galazka AM. The immunological basis for immunization series, module 2: diphteria. Global programme for vaccine and immunization expanded programme on immunization. Geneva: World Health Organization; 1993.

8. American Academy of Pediatrics. Diphtheria. Dalam: Pickering LK, penyunting. Red Book 2006. Report Committee on Infectious Diseases. Edisi ke-26. Elk brove Village: American Academy of Pediatrics; 2006. h. 277-81.

9. Wharton M, Vitek CR. Diphteria toxoid. Dalam: Plotkin SA, Orenstein WA, Offit PA, penyunting. Vaccines. Edisi ke-4. Philadelphia: WB Saunders; 2004. h.211-28.

10. Departemen Kesehatan. Petunjuk teknis bulan imunisasi anak sekolah (BIAS) bagi pengelola program. Jakarta: Tim Pembina UKS Pusat; 2007.

11. Tumbelaka AR, Hadinegoro SRS. Difteri, pertusis, tetanus. Dalam: Ranuh IGN, Suyitno H, Hadinegoro SRS, Kartasasmita CB, penyunting. Pedoman imunisasi di Indonesia. Edisi ke-2. Jakarta: Satgas Imunisasi-Ikatan Dokter Anak Indonesia; 2005.h.98-109.

12. Centers for Disease Control and Prevention. Immunization of adolescents: recommendations of the Advisory Committee on Immunization Practices, the American Academy of Pediatrics, the American Academy of Family Physicians, and the American Medical Association. MMWR Recomm Rep1996;45:1-16.

13. Departement of Vaccines and Biological. Supplementary information on vaccine safety. Part 2: background rates of adverse events following immunization. Geneva: World Health Organization; 2000.

14. Ipsen J Jr. Immunization of adults against diphtheria and tetanus. NEJM. 1954;251:459-66.

15. Edsall G, Altman JS, Gaspar AJ. Combined tetanusdiphtheria immunization of adults. Use of small doses of diphtheria toxoid, Am J Pub Health. 1954;44: 1537-45.

16. Levine L, Ipsen J, McComb JA. Adult immunization: preparation and evaluation of combined fluid tetanus and diphtheria toxoids for adult use. Am J Hyg. 1961;73:20-35.

17. Harun SR, Putra ST, Wiharta AS, Chair I, Sastroasmoro S.Uji klinis. Dalam: Sastroasmoro S, Ismael S, penyunting. Dasar-dasar metodologi penelitian klinis.Edisi ke-4. Jakarta: Sagung Seto; 2011. h. 187-217.

18. WHO. World Medical Association Declaration of
Helsinki: recommendations guiding physicians in biomedical research involving human subjects. Bull WHO. 2001;79(4):373-4.

19. Badan POM Republik Indonesia. Cara uji klinik yang baik. Jakarta: Badan POM; 2000

20. Bio Farma. Bandung: Vademekum Bio Farma; 1997.

21. Svenson SB, Larsen K. An enzyme-linked immunosorbent assay (ELISA) for the determination of diphtheria toxin antibodies. J Immunol Methods 1977; 17:249-56.

22. Galazka AM. The immunological basis for immunization series, module 1: general immunology. Global programme for vaccine and immunization expanded programme on immunization. Geneva: World Health Organization; 1993.

23. Tumbelaka AR, Riono P, Sastroasmoro S, Wirjodiardjo M, Pudjiastuti P, Firman K. Pemilihan uji hipotesis. Dalam: Sastroasmoro S, Ismael S, penyunting. Dasardasar metodologi penelitian klinis. Jakarta: Sagung Seto; 2011.h.324-46.

24. Batubara JRL. Adolescent development (perkembangan remaja). Sari Pediatri. 2010;12:21-9.

25. Isbagio DW, Handayani S, Siburian F, Sumarno. Pengaruh status imunisasi difteri pertusis dan tetanus terhadap respon kekebalan difteri dan tetanus pada murid kelas 1 sekolah dasar di kecamatan Cimandala. Bul Penel Kesehatan 2004;32:62-72.

26. WHO. Data, statistics and graphics by subject (diunduh 13 September 2010). Didapat dari: www.who.int. immunization_monitoring

27. Profil Kesehatan Indonesia 2005. Jakarta: Departemen Kesehatan RI; 2007.

28. Profil Kesehatan Indonesia 2008. Jakarta: Departemen Kesehatan RI; 2009.

29. Profil Kesehatan Indonesia 2009. Jakarta: Kementerian Kesehatan RI; 2010.

30. Matondang CS, Siregar SP. Aspek imunologi imunisasi. Dalam: Ranuh IGN, Suyitno H, Hadinegoro SRS, Kartasasmita CB, penyunting. Pedoman imunisasi di Indonesia. Edisi ke-2. Jakarta: Satgas Imunisasi-Ikatan Dokter Anak Indonesia Jakarta: 2005.h.10-22.

31. Akib AAP. Imunologi vaksinasi. Dalam: Oswari $H$, Hadinegoro SR, Trihono PP, Sekartini R, penyunting. $2^{\text {nd }}$ National symposium on immunization, Jakarta 19-21 November.Jakarta: IDAI; 2010.h.1-7.

32. Pichichero ME, Blatter MM, Kennedy WA, Hedrick J, Descamps D Friedland LR.Acellular pertussis vaccine booster combined with diphtheria and tetanus toxoids for adolescents. Pediatrics 2006;117:1084-93.

33. Barkin RM, Pichichero ME. Diphteria-pertusis-tetanus 
vaccine: Reactogenicity of commercial products. Pediatrics 1979; 63:256-9.

34. Fadlyana E, Tanuwidjaja S, Rusmil K, Dhamayanti
M, Soemara LS, Dharmayanti R. Imunogenisitas dan keamanan vaksin DTP setelah imunisasi dasar. Sari Pediatri. 2002;4:129-34. 